\title{
A dança costurando saberes sociais na educaçáo
}

\author{
Vanderléa Ana Meller ${ }^{1}$ \\ http://orcid.org/0000-0002-5342-2659 \\ Maria Glória Dittrich ${ }^{2}$ \\ http://orcid.org/0000-0003-2107-9005 \\ Isleide Steil ${ }^{3}$ \\ https://orcid.org/0000-0002-1844-3307 \\ Danielle Berbel Leme de Almeida ${ }^{4}$ \\ https://orcid.org/0000-0003-3808-2737
}

\section{Resumo}

Dançar é linguagem cultural humana de composição social que revela a organização do sentir e pensar humano, especialmente na educação. O objetivo deste estudo busca compreender a dança no enredo social da criança, na educação inscrita no percurso expressivo do desejo de ser, aprender e conviver. Foi desenvolvido um estudo de abordagem qualitativa, com base na hermenêutica fenomenológica, a partir de 10 oficinas de dança, com interação das crianças entre 5 e 11 anos de idade, de ambos os sexos, que frequentam instituiçóes educativas formais e não-formais, do Brasil/Itajaí/SC e de Portugal/Braga, e integram os projetos de atenção socioeducativa. A dança agregou oportunidades de criação artística e interação social no encadeamento expressivo; possibilitou a apropriação da diversidade cultural em relaçóes educativas que permitiram a emancipação humana, como sujeitos criadores do complexo mundo vivido, da cidadania atrelada à dança como patrimônio cultural; dançar envolveu o reconhecimento do ser humano de direitos e deveres que na convivência fortalece sua identidade cidadã.

Palavras-chave: Dança, Educação, Social.

\footnotetext{
${ }^{1}$ Doutora em Educação pela Universidade do Vale de Itajaí - UNIVALI. Professora na Universidade do Vale de Itajaí - UNIVALI. E-mail: vanderlea@univali.br.

${ }^{2}$ Doutora em Teologia - EST, Mestre em Educação - FURB e Bacharel em Filosofia - FEB. Professora da Universidade do Vale do Itajaí. E-mail: gloria.dittrich@univali.br.

${ }^{3}$ Doutoranda em Educação pela Universidade do Vale de Itajaí - UNIVALI. Professora da Universidade do Vale do Itajaí. E-mail: isleide@univali.br.

${ }^{4}$ Doutoranda em Estudos da Criança e Sociologia da Infância - CIEC- Centro de Investigaçáo em Estudos da Criança/Universidade do Minho (Portugal). E-mail: daniberbel@hotmail.com.
} 


\title{
Dance sewing social knowledge in education
}

\begin{abstract}
Dancing is a human cultural language of social composition that reveals the organization of the human feeling and thinking, especially in education. The aim of this study seeks to understand dance in the child's social scenario, in education inscribed in the expressive path of the desire to be, learn and live coexist. A study with a qualitative approach was developed, based on phenomenological hermeneutics, from 10 dance workshops, with the interaction of children between 5 and 11 years old, of both sexes, who attend formal and non-formal educational institutions, from Brasil / Itajaí / SC and Portugal / Braga, and are part of the socio-educational care projects. Dance added opportunities for artistic creation and social interaction in the expressive chain; it enabled the appropriation of cultural diversity in educational relationships that allowed human emancipation, as creative subjects of the complex world experienced, of citizenship linked to dance as cultural heritage; dancing involved the human being's recognition of rights and duties which, in coexistence, strengthens his citizen identity.
\end{abstract}

Keywords: Dance, Education, Social.

Conectando "retalhos" na educaçáo

Sou feita de retalhos. Pedacinhos coloridos de cada vida que passa pela minha e que vou costurando na alma. (PIZZIMENTI, 2017).

Dançar é "costurar" retalhos da arte, da cultura, da sociedade na composição de um conjunto repleto de diversidade humana, com infinitas formas e organizaçóes integra o patrimônio cultural local e mundial. Encontramos na dança o compartilhamento social na educação que possibilita trocas, "do ut des", do eu que se propóe a doar, para que o outro também tenha a oportunidade de dar. São laços que integram a compreensão humana nas relaçôes de trocas.

A dança é uma expressão tramada culturalmente nas heranças dos povos, nas inúmeras maneiras de extravasar emoçóes, de atividade física, de prática terapêutica, em brincadeiras de crianças e até em competiçôes. Todos, de uma forma ou de outra, dançamos em algum momento da vida e ao vivenciar o movimento incorporamos percepções de ser e conviver na experiência humana.

Tal experiência é significativa, principalmente para as crianças, quando é envolvida na co-presença de vários outros: outras crianças, outros adultos, 
outro tempo e outro espaço, assim organizam e definem outra possibilidade social e de confronto para com seus pares (FERREIRA, 2004).

Nossa capacidade de aprender está envolvida em processos de sentirpensar e a constituição do conhecimento perpassa o corpo integralmente e, neste sentido, nos auto-organizamos aprendentes em movimento, com imaginação e criação. A criança, em sua inquietude, na urgência de brincar e interagir, conhece o mundo envolvida por sensaçóes e percepçóes que permitem compreender e se constituir como sujeito social. Na visão ampla e integrativa dos propósitos sociais e humanos para viver a dança buscamos incluir e refletir com a temática da "costura". O foco envolveu as interaçóes e relaçóes sociais, em processos interculturais que foram desenvolvidas em instituiçóes escolares e socioeducativas do Brasil/Itajaí/SC e de Portugal/Braga.

A dança permite dialogar com o mundo, é eclética e coloca o corpo em constante movimento, construindo relaçóes com o eu e com o outro, no espaço e tempo que possibilita ampliar a consciência, o "alinhavar retalhos" de ser e saber, despertando conhecimentos conectados, pois "a dança não se faz apenas dançando, mas também pensando e sentindo: dançar é estar inteiro" (VIANNA, 2005, p. 32).

As crianças constituem, a todo o momento, seus modos de ser e interagir no mundo, para Garanhani (2010) suas danças comunicam a forma como participam do universo educativo e social, como um elemento identitário da infância, assim, o corpo assume um papel fundamental no processo de constituição da criança como sujeito cultural. A criança necessita agir para compreender e expressar significados presentes no contexto histórico-cultural em que se encontra e, ao transformar em símbolo aquilo que pode experimentar corporalmente, a criança constrói o seu pensamento sob a forma de dança no sentido de interagir e compreender os significados presentes no seu meio sociocultural.

Todo sujeito traz consigo sua história, a qual está impregnada no seu corpo e ressoa em suas açóes, falas, relaçôes, e principalmente, no seu modo de pensar e fazer dança. A história se constrói nas relações educativas e ao dançar a criança se relaciona com conhecimentos que são corporais com diferentes linguagens, pois “[...] o corpo não é um meio por onde a informação simplesmente passa, pois, toda informação que chega entra em negociação 
com as que já estão. O corpo é o resultado desses cruzamentos, e não um lugar onde as informações são apenas abrigadas" (GREINER; KATZ, 2001, p.71).

Ao valorizar o corpo e suas linguagens, colocamos as experiências corporais e a dança em lugar de destaque no campo da educação, seja em ambientes formais ou não-formais. Portanto, a dança como área de conhecimento se torna fundamental na construção de um ser social, político, ético, crítico, cultural e estético para as peculiaridades do homem no mundo. "Pensar a dança como arte na escola envolve pensar possibilidades de sensibilizar o educando, refinar seus gostos, ampliar seus saberes, propor mudanças" (STEIL; NEITZEL, 2019, p. 53).

Entre as práticas desenvolvidas, a dança integra uma oportunidade de envolvimento artístico e social no ambiente educacional. A partir das propostas desenvolvidas o objetivo deste estudo busca compreender a dança no enredo social da criança, na educaçáo inscrita no percurso expressivo do desejo de ser e conviver.

\section{O processo da costura}

Este é um estudo de abordagem qualitativa, com base na hermenêutica fenomenológica, realizada com crianças, meninos e meninas, com idades entre 5 e 11 anos, que frequentam instituiçôes educativas formas e não-formais do Brasil/Itajaí/SC e de Portugal/Braga. As práticas de dança desenvolvidas são integrantes das propostas educativas do projeto de Extensão "Mãos de Vida" da UNIVALI, desenvolvidas no Lar Fabiano de Cristo e Lar Padre Jacó; da disciplina Laboratório de Movimento Dança, do Colégio de Aplicação da Univali (CAU), na Educação Infantil; e no Colégio São Lazaro, na cidade de Braga em Portugal, com as crianças integrantes do Ensino Fundamental.

Foram desenvolvidas, em média, 10 oficinas presenciais, com 1 hora de duração, assim como recursos digitais na efetivação das práticas à distância. As práticas ocorreram semanalmente por meio de intervençóes organizadas com ambientes e estratégias apropriadas à dança e às intervençóes educativas. A partir da percepção dos pesquisadores os dados foram organizados e selecionados em categorias na busca da compreensão e descrição dos significados evidenciados.

É na diversidade da dança realizada em diferentes instituições educativas, no âmbito local e mundial, que encontramos um diálogo cultural 
e social, na expressão da arte que "costura" o saber, fazer e o conviver, possível na visão e proposta transdisciplinar.

\section{As costuras sociais da dança na educaçáo}

A dança no contexto cultural e social foi envolvida em uma ampla "costura" de saberes, na perspectiva transdisciplinar promoveu o pensar e o agir na complexidade do pensamento e nas relaçóes entre as pessoas, em prol da interação social e equidade. O dançar é diálogo nas relaçôes do humano e nas técnicas corporais que revelam percepçóes e significados constituídos no corpo em movimento, no humano incluído em uma relação de pertencimento social.

$\mathrm{Na}$ educação a arte se fez presente na dança envolvida na interação vivida, na dinâmica do grupo que compartilha desejos e realidades do conviver, em solidariedade coletiva e estados de bem-estar social, no compromisso com o conhecimento e a justiça social. Para Delors (2000, p. 11) "Ante os múltiplos desafios do futuro, a educaçáo surge como um trunfo indispensável à humanidade na sua construção dos ideais da paz, da liberdade e da justiça social”. São relaçóes de direito à educação que envolvem instâncias universais de alta relevância para o exercício da cidadania solidária, tendo em vista a defesa à vida, a ética em um convívio social digno.

$\mathrm{O}$ dançar possibilitou às crianças serem ao mesmo tempo propositores da ação coletiva e agentes unificadores do prazer de dançar, possível na liberdade de expressão, no envolvimento entre os pares e compartilhamento com os adultos com acordos e desacordos, presentes na ação reflexiva e apreensão de saberes e valores. Para Ferreira (2004), apropriados na interaçáo social do confronto e contraponto perante a ordem adulta surgem regras e princípios usados como conhecimentos e competências sociais para as crianças participarem no mundo adulto e ao mesmo tempo para se afirmarem perante ele. Neste contexto, identificamos que são ações educativas que oportunizam o protagonismo nas práticas, em processos de expressão criativa que despertam a liberdade e autonomia, e possibilitam condiçôes de interagir coletivamente.

Neste convívio, buscamos desconstruir os modelos tradicionais de ensino em que as crianças são representadas na hierarquia social como o aprendiz, ouvinte e passivo. Um modelo que, por norma, o adulto pensa, organiza e mapeia as atividades para a criança que, por sua vez, permanece 
afastadas dos núcleos centrais de decisão. Esse afastamento, sendo a expressão da dominação adulta, é um modo de hegemonia e de controle reafirmando que as crianças têm sido silenciadas na afirmação da sua diferença face aos adultos e na expressão autônoma dos seus modos de compreensão e interpretação do mundo (SARMENTO, 2011).

$\mathrm{O}$ modo como interpreta e significa seu mundo e os assuntos que lhe dizem respeito faz da criança um ator social que vai além da condição de aprendiz, a posiciona "[...] repórteres competentes da sua própria experiência de vida" e capazes de açóes dotadas de sentido e estruturadas de acordo com suas próprias lógicas (FERREIRA, 2002, p. 20).

As proposiçóes nas atividades socioeducativas posicionam a dança da criança como coparticipante e os remete ao lugar/espaço de busca pela objetividade e subjetividade do movimento de ser criança. Ao dançar eu encontro um propósito próprio da linguagem e da expressão, um processo no qual a criança é considerada como um sujeito ativo no seu processo de entendimento e reestruturação do conhecimento, valorizando suas contribuiçôes singulares (ALMEIDA; ANDRADE, 2016).

Aqui podemos estabelecer um paralelo entre o ato de dançar espontaneamente para apresentar ao outro, com o fato de precisar ensaiar e inventar uma dança para uma finalidade específica. Dançar de forma sistemática incute nas crianças um coletivo de aprendizagens resultantes da interação social entre eles, pois para transmitir às crianças determinados passos de dança, os adultos precisaram também incorporar os movimentos levando em conta que estavam aprendendo junto e construindo as relaçóes (ALMEIDA, 2017).

A dança como coreografia é relação, construída no e com o corpo em movimento, uma organização com liberdade e com normas que envolve percepção corporal, espaço, tempo e os outros corpos. O corpo dança ocupando o espaço, e a dança surge como lugar de sentidos e sensaçáo (KARAM, 2019). A coreografia possibilita a compreensão de como as crianças lindam em seus corpos para construir significados e sentimentos, compartilhando em seus relacionamentos os desejos, ambientes e recursos que favorecem comportamentos e desenvolve desafios corporais. Ocorre a organização de posiçóes sociais, como liderança e obediência, e de como desempenham tais posiçóes nas comunicaçóes corporais no desenrolar do processo (MANSO et al., 2017). O dançar envolve uma prática que estimula 
o pensar e agir no contexto da sociedade e funçóes de cidadania desempenhadas, pois cada um necessita encontrar seu lugar na coreografia, ao mesmo tempo que reconhece e respeita o lugar do outro.

Buscamos expressar e refletir em torno da pluralidade cultural, as relaçóes discursivas que permeiam o corpo e que limitam a interação e expressividade. Muitas vezes são os processos disciplinadores que anulam o corpo, calando, distanciando e padronizando o dançar. Permitir o corpo físico dialogar é um desafio ao pensamento que é afetado no contato sensível em diferentes ritmos e compassos. Se cada passo é um retalho, nossa coreografia é uma grande "colcha de retalhos" costuradas na liberdade criativa.

Uma das propostas envolvendo a dança, na perspectiva interativa e transdisciplinar, envolveu a articulação das relações sociais e diversidades com o compromisso da justiça social, buscando desvelar mecanismos instrumentalizadores que calam os sujeitos e desprezam as interrelaçóes. A temática envolvida foi a "costura" na construção coreográfica e expressiva, articulando simbolicamente os propósitos da ação. Costurar é sinônimo de alinhavar, e nos remete a ação de unir duas ou mais coisas, e nesse sentido, a ideia se deu tanto no contexto amplo, em unir as diferentes linguagens, expressividade e conhecimentos, como no contexto específico, na criação de movimentos e na relação desses com os sentimentos. As questóes que permearam o propósito da produção coreográfica foram: Como é possível costurar os sentimentos? Como é possível alinhavar o meu sentimento com o de um amigo ou familiar na dança?

Para o registro da dança foi solicitada a elaboração de um pequeno vídeo, com movimentos dançantes representando a ideia de "costurar os sentimentos". Para isso, a professora de dança, integrante do Projeto de Extensão "Mãos de Vida", elaborou um vídeo, com a sequência didática para a produção da dança, com a proposta simbólica de cada um costurar os sentimentos e movimentos na produção de um "retalho" para compor uma da "colcha de retalhos", ou seja, a coreografia como um conjunto de linguagens do ser e conviver. A poesia "Colcha de retalho", da autoria de Cris Pizzimenti, foi articulada para sensibilização e reflexão dos propósitos da costura e de como ela acontece, em movimento, em diferentes trajetos, por linhas ondulares, redondas, retas ou sinuosas.

O objetivo da atividade foi de se reconhecer na construção social da arte de dançar e conviver, de criar e deixar aflorar o mais sinceros sentimentos 
e movimentos que expressam o ser humano presente, o que está atrelado à história de cada corpo. Após, com todas as filmagens, a ideia foi de unirmos cada parte, os "retalhos" e construirmos a grande "colcha de retalhos", em uma coreografia digital, uma colcha composta e ilustrada pela dança. Uma composição que possibilita nos fortalecermos na coletividade, como sujeitos criadores e interconectados ao movimento e ao outro. Esta proposta foi fundamental em virtude do momento que estamos vivendo, de distanciamento ocasionado pelo Covid-19, e que possibilita a expressão e o encontro com o outro.

Dançar envolve uma expressividade nutrida de plasticidade, modelada pelo imaginário e habilidades físicas que se articulam na totalidade humana. Quem dança tem a oportunidade de se envolver em uma coreografia corporal social, psicológica, cultural, biológica... A arte de dançar promove a performance no desenvolvimento da criação como possibilidade de compreender a si mesmo, ao outro e ao meio em que vive. O engajamento é amplo, pois ocorre a construçáo de lugares e tempos partilhados no diálogo expressivo e reflexivo.

Porém, a busca pelo seu lugar na dança, pela sua individualidade, requer corpos disponíveis e conscientes das suas possibilidades de movimento, e isso se dá a partir do contato com arte, mas também, pela interação do professor no instigar a relação com a criança, entre os processos internos e o externos do corpo, pois "[...] devemos buscar compreender e assimilar nossa interdependência com o espaço, esquecendo a forma, que, quando preconcebida, é morta, estática, acomodada e impede o aprendizado, o aperfeiçoamento e a criação de novos gestos" (VIANNA, 2005, p. 105).

Foi possível identificar o quanto há por parte das crianças a dificuldade de expressar os sentimentos e movimentos, pois nossa "colcha" ficou reduzida, ocorreu um grande bloqueio na produção dos "retalhos", pois ocorreu o retorno da gravação da dança de um educando apenas. Os argumentos expressos em torno das dificuldades da produção foram que não sabiam como dançar na proposta e que não entenderam a atividade solicitada. Este foi um momento de ampla reflexão por parte dos professores, pois a dança nesta instituição educativa e social tem o propósito inclusivo e emancipatório. Não conseguimos atingir o grupo, avaliamos que a proposta era adequada à idade, porém expressar os sentimentos de amor e compaixão não foram tarefas fáceis. 
Frente a esta realidade enfrentamos o desafio de estimular a afetividade, necessária à inclusão social, e minimizar os bloqueios psicossociais que dificultam a expressão de sentimentos e a própria criatividade. Necessitamos criar uma proposta de expressão amenizando sentimentos compartilhados e instigando sentimentos pessoais. Avaliamos o quanto os princípios da equidade integram as condiçóes do ser humano de interpretar e compreender seu mundo, e que respeitar as dificuldades emocionais e afetivas integram os princípios da justiça social, de sermos solidários perante as dificuldades, fragilidades e sofrimentos do humano.

$\mathrm{Na}$ relação didática, foi necessário identificar as dificuldades do grupo e criar uma condição acolhedora às diversidades e realidades. Reconhecemos o quanto as crianças tiveram o receio de expor seus sentimentos e que precisam ser respeitadas, porém também encorajadas a ressignificar o que sentem. A expressão dos sentimentos afetivos é fundamental nas relaçóes sociais, na conexão amorosa, assumindo a autoria da sua própria dança e da condição humana, do ser e conviver nos corpos dançantes. Foi necessário revisar os silenciamentos impostos pelos modelos disciplinadores e de distanciamento afetivo apresentados às crianças, historicamente, e favorecer os contatos expressivos.

Neste contexto, um segundo vídeo foi elaborado na busca da interconexão social e encorajamento pessoal para estabelecer ligação com o outro, como a amizade, fundamentais para a criança. Machado (2010, p. 60) anuncia que "para deixar fluir a temporalidade da criança, há que deixá-la ser: permitir que experiencie o mundo a seu tempo, dando espaço para que seu modo próprio se estabeleça e se expresse, em seu ritmo".

A reflexão possibilita romper com padrôes que estão estabelecidos em modelos técnicos, pois o dançar é questionar, é problematizar e transpor as condiçóes disciplinadoras e excludentes. Participar de um grupo de dança é uma oportunidade inclusiva, de interagir e integrar um ambiente e momento de criação. Um processo educativo comprometido com a vida e a sociedade, desde a promoção de pessoas, produção e socialização de conhecimentos visando aprendizagens de ligação e respeito aos ambientes vitais, tendo em vista o desenvolvimento do exercício da cidadania. "A vida é a síntese do corpo e o corpo é a síntese da vida” (VIANNA, 2005, p. 103).

Buscamos uma educação transformadora que mobiliza as pessoas e consequentemente a sociedade, que considera as necessidades emergentes no 
contexto da construção do conhecimento criativo, com saberes necessários e ampliados envolvendo a interligação entre o humano, a arte e a sociedade. $\mathrm{O}$ desafio das práticas educativas, que tem a pretensão de favorecer a interação social, é propor de modo acessível a fim de não promover mais exclusóes e constrangimentos. É preciso buscar "uma mediação que provoque o outro a construir proposiçóes, suas próprias narrativas por meio do corpo [...]" (STEIL; NEITZEL 2019, p. 78).

A independência na criação de movimentos dançados ou desvincular da forma pronta, não é algo fácil para sujeitos que nunca vivenciaram práticas de criação, percepçáo e reflexão da dança. O aprender movimentos preestabelecidos pelo professor, ainda é uma prática muito frequente nas aulas de dança, e é natural para o aluno, que está habituado a esse padrão, sentir medo ou vergonha de errar ao tentar extrapolar essa dinâmica. Por isso, a importância do mediador de dança buscar "educar e tornar fluente a naturalidade do gesto, até o momento em que o aprendizado se converte num hábito, como parte de uma dinâmica corporal que assimila e ao mesmo tempo transcende os limites do próprio aprendizado” (VIANNA, 2005, p. 101).

A interpretaçáo dos elementos permite a reflexão sobre os contextos da arte e da cultura a partir da criação que supera os códigos vigentes em modelos mecanicistas e excludentes que aprisionam o corpo em seu sentir-pensar-agir. Nos processos educativos confiamos nas capacidades humanas de

Abrir nossa gaiola para que possamos elevar nossa consciência educadora voltada [...], sobretudo, para a transformaçáo de nossos pensamentos, de nossos hábitos, valores, atitudes e estilos de vida. Esta é uma das condiçốes necessárias não apenas para o desenvolvimento de processos cognitivos, mas também para reencontrar a paz, a saúde, a harmonia, a justiça social que sempre buscamos e para reencontrar os ideais que professamos (MORAES, 2010, p. 1)

Transformar implica dar oportunidade ao sujeito expressivo e reflexivo, quebrando os padróes mecanicistas por meio da dança, criando novas gestualidades no reencontro com suas singularidades, para o conhecimento de si e do outro, possível no corpo em movimento. Abrir a "nossa gaiola" na libertação do corpo institucionalizado e na busca do corpo singular é promover a "costura" que se expressa na sinceridade de seus movimentos. O dançar que favorece a capacidade de autoconhecimento e de ser humano 
social, político, cultural e crítico é fundamental na constituição do ser humano como presença viva frente as adversidades.

As danças circulares foram práticas que mobilizaram as manifestaçôes expressivas e culturais de movimento em processos interativos e cooperativos. As danças circulares estão incluídas nas Práticas Integrativas e Complementares (PICS), favorecendo os cuidados educativos e saúde integral. As relaçóes sociais e culturais da circularidade da dança envolvem a prática expressiva de conexão e harmonia na coletividade, envolvidos no canto e seus ritmos. (BRASIL, 2017). Nesta perspectiva foram desenvolvidas diversas práticas com as crianças participantes do Projeto de extensão "Mãos de vida", nos propósitos da interação social e acesso às práticas transdisciplinares, estabelecendo conhecimentos e práticas integradoras do humano com o meio. Os retalhos que compuseram o aparelho circular manipulado pelas crianças ao dançar, chamado "paraquedas", representou a "colcha de retalhos" colorida e circular, possibilitando a "costura" da diversidade dos sujeitos e dos saberes em movimento e expressão.

Para Torre (2008, p. 36), “[...] um olhar "Trans" tem seus impactos e relevância que vão além do conhecimento porque é uma maneira de saber, de saber fazer, de saber ser e estar em qualquer atividade humana". $\mathrm{Na}$ interconexão dos conhecimentos e práticas os profissionais envolvidos teceram a temática da "costura" articulando saberes e favorecendo a complexidade em um constante ensinar/aprender com abertura à sensibilidade-racionalidade da arte, da ciência e das humanidades nas descobertas para o ser, fazer e viver a cidadania, que vai se construindo nas relaçóes de acolhimento e capacitação.

$\mathrm{Na}$ interação geral e das especificidades profissionais foram integradas atividades da dança como expressão criativa, em movimento na construção coreográfica, com práticas que aprimoram condiçóes sociais nas propostas transdisciplinares. Para Moraes (2010, p. 1),

A transdisciplinaridade, nutrida pela complexidade, exige de cada docente a criação de ambientes e contextos de aprendizagem mais dinâmicos e flexíveis, mais cooperativos e solidários, a criação de ecossistemas educacionais nos quais prevaleça a solidariedade, a parceria, a ética, a generosidade, o companheirismo, o diálogo na busca constante de soluçóes aos conflitos emergentes, bem como o respeito às diferenças e o reconhecimento da diversidade cultural, da existência de diferentes estilos de aprendizagem que tanto enriquecem as 
experiências individuais e coletivas, experiência que tanto embelezam nossas vidas.

A educação, envolvida na complexidade, ocorre com interligaçóes de saberes e responsabilidades sociais com base no respeito a diversidade, a equidade, proteção social e diretos humanos. Os valores sociais foram incluídos nas danças circulares, envolvendo momentos de diálogos reflexivos em torno das condiçóes de vida, direitos, deveres e sentimentos envolvidos na convivência. O simbolismo dos gestos e as atitudes possibilitaram a ressignificação do dançar na coletividade, do dançar juntos. Para Silva (2017), ao dançar na circularidade é possível estabelecer contatos sinergéticos no encontro com o outro e consigo mesmo, ocorre a comunhão, portanto a inclusão ampla do humano em harmonia e acolhimento na roda. O ser social se faz presente ao compartilhar momentos, movimentos e sentimentos que ligam os corpos.

As músicas e letras que compóe as cançôes escolhidas tiveram um foco na vivência social e no fortalecimento das relaçóes humanas. No dançar foram desafiados a promover desejos de convivência e açóes para compartilhar e incluir no cotidiano. Muitas expressóes foram importantes na consolidação da integração e para um clima de solidariedade e justiça social no grupo, no qual cada um foi respeitado por suas diferenças e acolhido em suas dificuldades. A busca coletiva na resolução das problemáticas do grupo foi fundamental para a visão crítica e inclusiva, no reconhecimento do respeito às diferenças.

Em cada encontro, em cada contato, vou ficando maior... Em cada retalho, uma vida, uma lição, um carinho, uma saudade... 
Figura 1 - Práticas educativas com danças circulares.

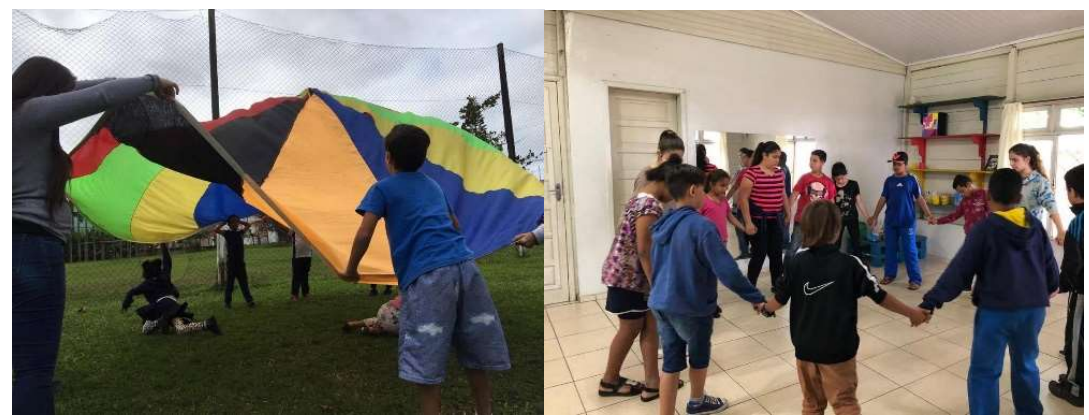

Fonte: Arquivo das pesquisadoras.

Por meio das danças circulares foi possível a transição de modelos individuais para perspectivas coletivas na interação com o outro, no fortalecimento social. As diferenças e desejos divergentes foram primordiais para a busca do entendimento nas relaçóes de ser e conviver. O respeito ao outro em suas singularidades e expressóes de sentimentos com amorosidade foram "costurados" com atitudes relevantes.

$\mathrm{Na}$ circularidade foi possibilitado o contato direto das "mãos dadas", a concentraçáo e memória com ritmos e melodias que envolveram sentimentos e significados, aflorados por diversas cantigas e músicas que possuíram composições apropriadas às temáticas trabalhadas. Foram organizadas dinâmicas humanizadas que instigaram o "dançar com" o outro, com recursos para estimular a criatividade, como o tecido do brinquedo "paraquedas" que simbolizou a diversidade e a circularidade. (MELLER, et al. 2020, p. 64-65).

A dança como arte social promoveu o encontro do sentido de ser e conviver, é muito além do se mover ao som da música, pois articulou relações de diferentes campos, e assim se tornou uma oportunidade de refletir sobre o humano em movimento e comunicação em diversos meios sociais e políticos, inclusive na escola.

No Colégio de Aplicação da UNIVALI, no âmbito da Educação Infantil, foi muito importe aproximar as crianças do folclore brasileiro o que possibilitou "costuras" culturais na história, nos costumes e nas tradiçôes 
regionais, pois "[...] o folclore é sinônimo de cultura popular e representa a identidade social de uma comunidade através de suas criaçóes culturais, coletivas ou individuais, e é também uma parte essencial da cultura de cada nação" (SOUZA, 2013, p. 160).

Temáticas que envolvem manifestações artísticas e culturais possibilitaram o diálogo, o respeito às diferenças, e um deslocamento imaginativo para um espaço desconhecido e rico culturalmente, com conhecimentos e tradiçóes da dança de uma determinada cultura que "[...] representa ou simboliza significativos valores e crenças do povo que partilha esta dança, refletindo o maior sistema de conhecimento cultural do grupo e dos indivíduos" (SOUZA, 2013, p. 158).

$\mathrm{Na}$ "costura" cultural, que expressa maneiras criativas de estabelecer relaçôes, foi trabalhada a dança do Bambu, uma dança de origem indígena praticada no sudeste e noroeste do Brasil. A contextualização, apreciação, vivência e discussão sobre essa tradição possibilitou a construção de saberes incorporados, pois conta a história de um povo e do Brasil, e as singularidades das linguagens.

Figura 2 - Prática educativa com a Dança do Bambu

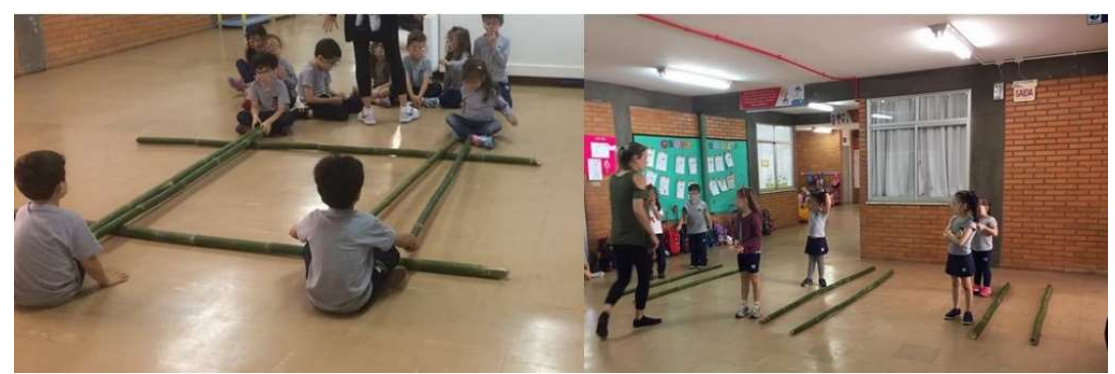

Fonte: Arquivo das pesquisadoras

A prática da dança indígena possibilitou conhecer e vivenciar uma manifestação cultural com relaçóes ecológicas no espaço coletivo e conhecimentos que emergissem das interaçóes. Nessa atividade foi proporcionado a interação, socialização, o desenvolvimento do ritmo com o auxílio do bambu, que nesse caso, se torna um instrumento musical, o respeito e a cooperação ao tempo de aprendizagem do colega, pois essa é uma dança coletiva que necessita da prática coordenada do grupo como um todo. 
Manifestando a integraçáo cultural dos povos e demonstrando a interligação mundial, a prática do grupo de dança para a celebração do Natal estabeleceu aproximaçóes ao ser desenvolvida no Colégio São Lazaro, na cidade de Braga, em Portugal. As crianças dançaram uma coreografia para a festa de natal construída e constituída coletivamente, resultando em um fator identitário da turma $\mathrm{B}$, com o envolvimento da professora e da auxiliar que mantiveram com as crianças o prazer de dançar junto como forma de celebração. Pois, para além de dançar com as outras crianças ocorreu o envolvimento direto dos adultos, toda construção foi parte integrante da alegria de dançar.

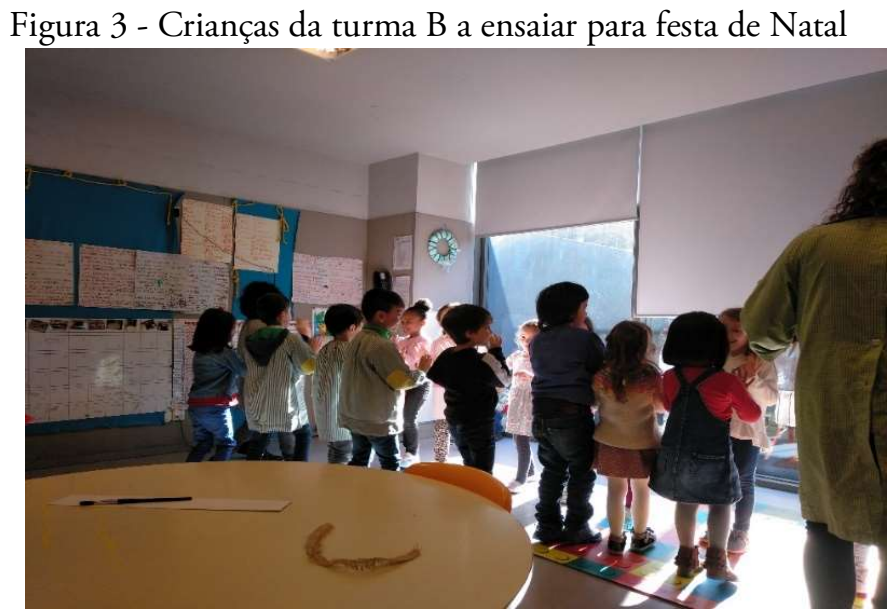

Fonte: Arquivo das pesquisadoras

As apresentações de danças nas festas e celebrações é culturalmente representado nas mais variadas formas e participaçôes, é de certa forma patrimônio de cada povo e, as danças são passadas de geração para geração onde as crianças são envolvidas de inúmeras formas nas aprendizagens e nas interaçóes relacionais. O papel social da dança nas celebraçóes com o dançar e o assistir a dança sempre juntou corpos, geraçôes e tradiçóes nas mais abrangentes representatividades.

A festa é um espaço que são manifestadas experiências e expectativas de futuro, pois os seus elementos constitutivos e entre esses se encontra 
a dança, nela pode ser diluída, celebrada, ritualizada e ironizada as experiências sociais. Diríamos que são, ainda, o modo de se resolver, ao menos no plano simbólico, algumas das contradiçóes da vida social (ANJOS, 2013, p.5).

Dançar é rito, festa, estilo, ritmo, encontro, relação e nela assumimos os riscos da criaçáo no desafio de se sentir inteiro na "costura dos retalhos". Uma costura que alinhava o ser humano de direitos e deveres, estético e ético que enfrenta os desafios com presença perante os enfrentamentos e resistências sociais.

\section{Consideraçōes Finais: Alinhavando os últimos retalhos...}

E a melhor parte é que nunca estaremos prontos, finalizados [...] Haverá sempre um retalho novo para adicionar à alma. (PIZZIMENTI, 2017).

Ser "costureiro" na complexidade é desafiador no emaranhado de saberes, fazeres e convivência que provoca processos intuitivos e nos desafia a pensar. Este coser envolve fazer escolhas e discernir entre os "pontilhados", as ligaçóes, que ampliam a cidadania e a força da justiça social em prol do bemestar e da paz que envolvem relaçóes de cuidado de si, do outro e do ambiente que vivemos.

"Alinhavar" a conexão do pensar e fazer dança proporcionou costuras de saberes, para além do repertório de movimento. É um coser na arte que perpassa linhas de ligação no sujeito, no outro e nas relaçóes estabelecidas, constituindo o conhecimento integrado, como uma grande "colcha de retalhos", que acolhe os sentimentos, as percepçóes e entendimentos do ser cidadão.

Dançar possibilitou tramar as linhas sociais que teceram os nós de significaçôes na compreensão da empatia, cooperação, solidariedade, alteridade e coletividade. A visão cidadã, como ser de direitos e deveres, se articulou nas relaçóes estabelecidas no dançar com o outro e o seu movimento/pensamento que reflete dialogicamente.

Muitas foram as oportunidades de expressão artística na dança com envolvimento de interação social, possibilitando a apropriação da diversidade 
cultural e humana. Os processos educativos envolveram a emancipação humana na criação, empregando um sentido de ser humano de cidadão possível no compartilhamento.

\section{Referências}

ALMEIDA, F.; ANDRADE, C. Dançar com a criança: um olhar para a composição e criação em dança com a pequena infância. Revista Cientifica/FAP, v.1 5, n. 2, p. 10-30, jul./dez. 2016.

ALMEIDA, D. B. L. Considerações finais (ou iniciais) da com-posição coreográfica. In: Almeida, D. B. L. (Org.). Criando coreografias na escola. Novas Ediçóes Acadêmicas, 2017. p. 73-74.

ANJOS, J. L. Festa, danças e representações: continuidade de tradições e plasticidades culturais. Movimento, Porto Alegre, v. 19, n. 3, p. 11-30, jul./set. 2013.

DELORS, J. (0rg.). Educação: um tesouro a descobrir: relatório para a Unesco da Comissão Internacional sobre Educação para o século XXI. 4. ed. São Paulo: Cortez, 2000.

FERREIRA, M. A gente aqui o que gosta mais é de brincar com os outros meninos!: as crianças como actores sociais e a (re)organização social do grupo de pares no quotidiano de um jardim de infância. Tese (Doutorado em Ciências da Educação) - FPCE, Porto, 2002.

FERREIRA, M. Do "avesso" do brincar ou... as relaçóes entre pares, as rotinas da cultura infantil e a construção da(s) ordem(ens) social(ais) instituinte(s) das crianças no jardim-de-infância. In: SARMENTO, M. J.; Cerisara, A. B. (org). Crianças e miúdos: perspectivas sociopedagógicas da infância e educação. Porto: Ediçóes ASA, 2004, p. 55-104.

GARANHANI, M. C. Educação Física. In: PARANÁ. Secretaria de Estado da Educação (Org.). Ensino fundamental de nove anos: orientaçôes pedagógicas para os anos iniciais. Curitiba. 2010.

GREINER, C.; KATZ, H. Corpo e processos de comunicação Revista fronteira-estudos midiáticos, [s. l.], v. III, n.02, p. 65-71. 2001. 
KARAM, S. Meu corpo precisa ocupar espaço. Cadernos de literatura comparada, n. 41, p. 81-99. 2019.

MANSO S., FERREIRA, M.; VAZ, H. Children's play events as improvisational choreographies. International Journal of Play, [s. l.], n. 6, v. 2, p. 135-149, 2017.

MACHADO, M. M. Merleau-Ponty \& a educação. Belo Horizonte: Autêntica, 2010.

MELLER, V. A. et al. Danças circulares: interconectando educação e saúde. In: Diálogos sobre a vida: Política, educação e saúde. Itajaí: Ed. Univali, 2020.

MORAES, M. C. Transdisciplinaridade e educação. Revista Rizoma Freiriano. v.6, 2010. Instituto Paulo Freire de España. Disponível em: http://www.rizoma-freireano.org/transdisciplinaridade-e-educacao--mariacandida-moraes. Acesso em: 10 jul. 2020.

PIZZIMENTI, C. Sou feita de retalhos. Revista Consciência, 2017. Disponível em https://revistaconsciencia.com/sou-feita-de-retalhos. Acesso em 15 jul. 2020.

SARMENTO M. J. Conhecer a infância: os desenhos das crianças como produçôes simbólicas. In: FILHO, A. M.; PRADO, P. D. (org.). Das pesquisas com crianças à complexidade da infância. Campinas: Autores Associados, 2011. p. 27-60.

SOUZA, M. C. Danças populares: processos de criação e performance. In: SOUZA, Marco Aurélio da C. (org.). Impressóes corporais e textuais: pesquisa em dança. São Paulo: All Print Editora, 2013, p. 151-179.

STEIL, I.; NEITZEL, A. A. Por uma escola que dança. Curitiba: CRV, 2019. TORRE, S. L; PUJOL, M. A.; MORAES, M. C. Transdisciplinaridade e ecoformação: um novo olhar sobre a educação. Tradução Susana Vidigal. São Paulo: TRIOM, 2008.

VIANNA, K. A dança. São Paulo: Summus, 2005.

Recebido em: 07 ago. 2020

Aceito em: 22 ago. 2020 